\title{
SUNGAI MARO: SALAH SATU SUMBER PLASMA NUTFAH JENIS IKAN ASLI PAPUA
}

\author{
Andri Warsa1), Lismining Pujiyani Astuti'1), dan Hendra Satria1) \\ ") Peneliti pada Loka Riset Pemacuan Stok Ikan, Jatiluhur-Purwakarta \\ Teregristrasi I tanggal: 23 Januari 2007; Diterima setelah perbaikan tanggal: 23 Januari 2007; \\ Disetujui terbit tanggal: 21 Maret 2007
}

\begin{abstract}
ABSTRAK
Sungai Maro berada di Kabupaten Merauke Propinsi Papua dengan lebar 48 sampai dengan 900 $\mathrm{m}$ dan panjang $207 \mathrm{~km}$. Jenis-jenis ikan yang merupakan kekayaan plasma nutfah di Sungai Maro dapat dibagi menjadi 2 kategori yaitu ikan hias antara lain arwana Irian (Sclerophages jardinii), sumpit (Toxotes sp.), kurikil (Datnioides sp.), udang batu cherax (Cherax albertisi), kakap kembang (Golssamia apton), kaca (Parambassis sp.), tung (Apogon sp.), saku (Strongylura kreffti), dan yang berpotensi sebagai ikan konsumsi antara lain tiga duri atau herkules (Arius latirostris), tulang (Megalops cyprinoides), sembilan (Taudonus sp.), mata bulan (Thryssa scratchleyi), gastor (Channa sp.), betok (Anabas sp.), udang putih (Marcobrachium sp.), kakap rawa (Lates calcarifer), dan bulanak (Valamugil sp.). Perlu upaya pengembangan yang mengacu pada prinsip-prinsip konservasi untuk menjaga kelestarian.
\end{abstract}

KATAKUNCl: Sungai Maro, plasma nutfah, ikan asli Papua

\section{PENDAHULUAN}

Wilayah Sungai adalah kesatuan wilayah pengelolaan sumber daya air dalam satu atau lebih daerah aliran sungai dan atau pulau-pulau kecil yang luas kurang dari atau sama dengan $2.000 \mathrm{~km}^{2}$. daerah aliran sungai merupakan suatu wilayah daratan yang merupakan satu kesatuan dengan sungai dan anak sungai yang berfungsi menampung, menyimpan, dan mengalirkan air yang berasal dari curah hujan ke danau atau ke laut secara alami, yang batas di darat merupakan pemisah tofografis dan batas di laut sampai dengan daerah perairan yang terpengaruh aktivitas daratan (Undang-Undang No.7 tahun 2004). Sungai Maro berada di wilayah administrasi Kabupaten Merauke Propinsi Papua dan merupakan salah satu daerah penangkapan ikan arwana Irian (Sclerophages jardinii). Sungai ini dimanfaatkan untuk kegiatan transportasi dan perikanan tangkap sehingga merupakan salah satu sungai di Kabupaten Merauke yang memberi kontribusi perikanan yang besar. Lebar sungai 48 sampai dengan $900 \mathrm{~m}$ dan panjang sungai 207 km (Dinas Perikanan Kabupaten Merauke, 2005a). Di sungai ini banyak terdapat rawa yang ditumbuhi tanaman air yang berfungsi sebagai tempat memijah dan daerah pembesaran (nursery ground) bagi ikan.

Keanekaragaman hayati merupakan istilah yang digunakan untuk menerangkan keragaman ekosistem dan berbagai bentuk variabilitas hewan, tumbuhan, dan jasad renik di alam. Dengan demikian, keanekaragaman hayati mencakup keragaman ekosistem (habitat), jenis (spesies), dan genetik (varietas atau ras) (Dahuri, 2003 dalam Pusat Riset Perikanan Tangkap, 2005) atau merupakan istilah yang mengacu pada berbagai kehidupan di bumi. Secara umum, kajian menyangkut 3 tingkatan, yaitu keanekaragaman genetik, jenis, dan ekosistem. Sumber daya alam hayati beserta ekosistem, dipahami selama ini menjadi sasaran pemanfaatan untuk memenuhi berbagai kebutuhan manusia. Pemanfaatan sumber daya tersebut, yang antara lain dikenal dalam bentuk kegiatan pertanian, kehutanan, peternakan, dan perikanan merupakan serangkaian kegiatan yang diharapkan dapat juga meningkatkan kualitas hidup manusia.

\section{IKAN ASLI SUNGAI MARO}

Ikan adalah semua biota perairan yang sebagian atau seluruh daur hidup berada di dalam air, dalam keadaan hidup atau mati termasuk bagian-bagian (Undang-Undang Perikanan No.31 tahun 2004). Di Sungai Maro terdapat arwana, ikan tulang, kakap rawa, kakap kembang, saku, sembilan, mata bulan, udang putih, ikan sumpit, ikan kaca, dan lobster air tawar. 


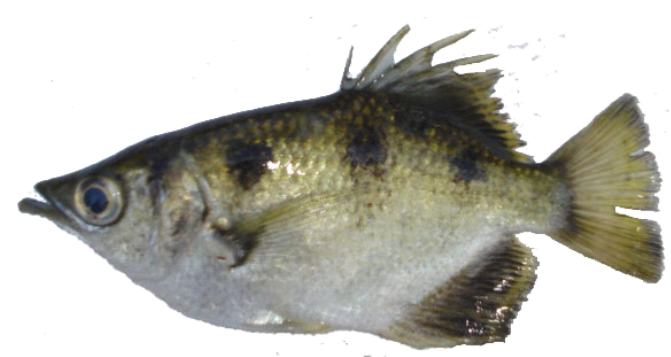

Sumpit (Toxotes sp.)

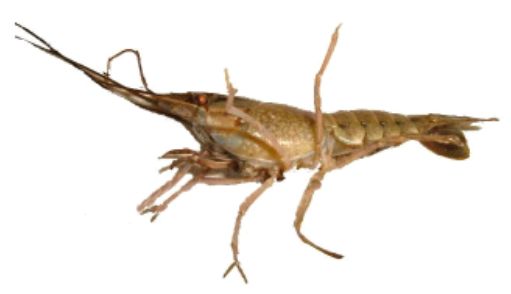

Udang batu atau Lobster (Cherax albertisi)

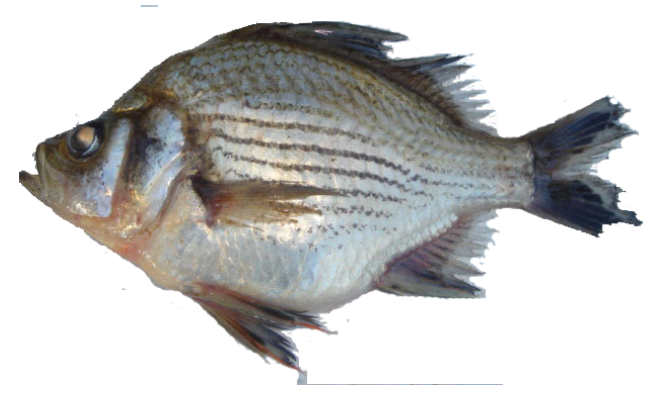

Kaca (Parambassis sp.)

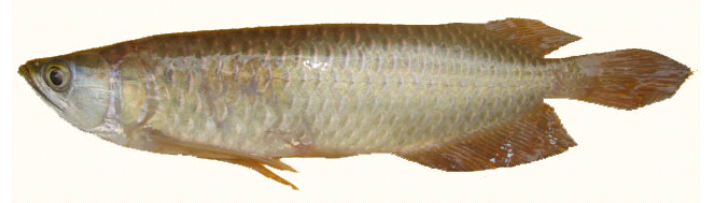

Arwana Irian (Sclerophages jardinii)

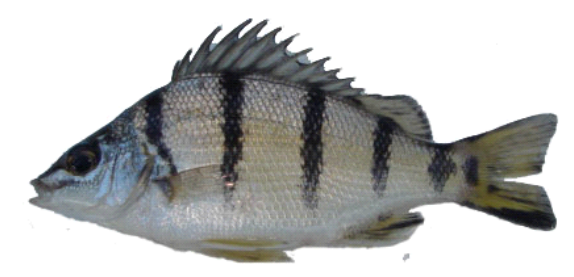

Kurikil (Datnioides sp.)

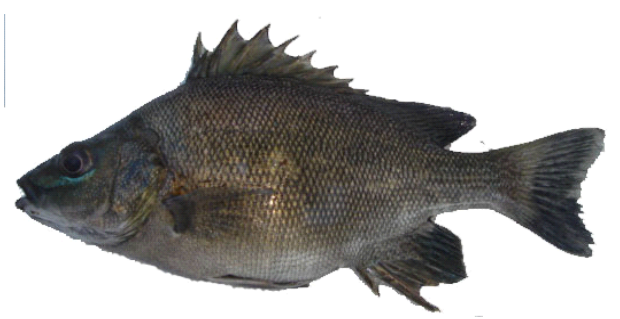

Kakap kembang (Golssamia apton)

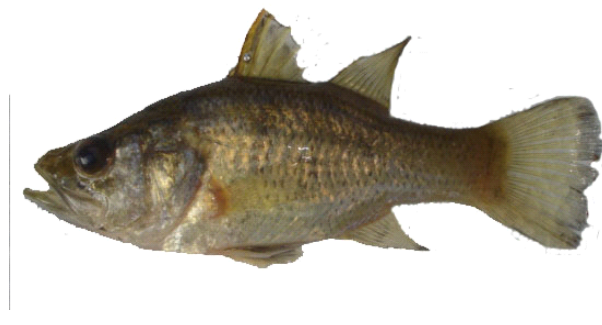

Tung (Apogon sp.)

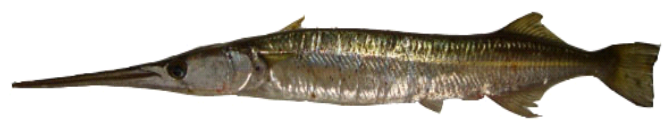

Saku (Strongylura kreffti)

Gambar 1. Beberapa jenis ikan yang berpotensi dikembangkan sebagai ikan hias. 
Sungai Maro juga merupakan sentra ikan arwana (Scleropages jardinii) yang merupakan ikan hias yang indah dan berharga mahal. Habitat ikan arwana di Sungai Maro berupa rawa dengan banyak tumbuhan air karena menjelang memijah ikan ini akan menuju rawa dan pemijahan berlangsung di tempat yang berarus tenang dan tumbuhan air berfungsi untuk tempat berlindung (Tjakrawidjaja \& Haryono, 2003). Ikan ini dapat ditangkap untuk keperluan penangkaran pola pengembangbiakan (captive breeding) dan pembesaran anakan (ranching), upacara adat setempat, kebutuhan pangan setempat, serta perdagangan dalam dan luar negeri.

Ikan yang dapat dikembangkan sebagai ikan hias (Gambar 1) selain ikan arwana antara lain ikan saku, kurikil, sumpit, tung, kakap kembang, dan kaca. Masing-masing ikan mempunyai keunikan dan ciri khas tersendiri sebagai ikan hias. Ikan sumpit mempunyai totol hitam yang berjumlah 6 sampai dengan 7 buah dan 3 antara lain lebih besar dari yang lain. Ikan ini mempunyai kemampuan untuk menangkap mangsa dengan menembakkan butiran air. Warna dominan ikan kaca adalah perak dengan garis hitam berjumlah 8 sampai dengan 9 pada tubuh bagian samping. Sirip pada bagian dubur dan perut berwarna kuning dengan panjang standar maksimum dapat mencapai $180 \mathrm{~mm}$ tetapi juga pernah ditemukan ikan dengan ukuran $240 \mathrm{~mm}$. Ikan Saku mempunyai warna dominan perak pada bagian sisi dan pada bagian punggung berwarna coklat sampai dengam kehijauan pada bagian belakang. Sirip berwarna kehitaman (Allen, 1991; Allen et al., 2000). Moncong ikan saku di bagian depan merupakan ciri khas yang unik dan menambah keindahan ikan ini. Untuk lobster dan kakap kembang dapat dikembangkan sebagai ikan konsumsi yang bernilai ekonomi tinggi.

Beberapa jenis ikan hias Kabupaten Merauke yang telah dipasarkan ke luar daerah disajikan pada Tabel 1.

Tabel1. Pemasaran ikan hias antar pulau, tahun 2004

\begin{tabular}{clcl}
\hline No & \multicolumn{1}{c}{ Nama jenis ikan } & Jumlah (x 1000 ekor) & \multicolumn{1}{c}{ Daerah penyebaran } \\
\hline 1 & Arwana (Scleropages jardini) & 100 & $\begin{array}{l}\text { Rawa Biru (Merauke), Muting, dan } \\
\text { Okaba }\end{array}$ \\
2 & Bambit (Selanota multifasciata) & 315 & Merauke, Muting, Okaba, dan Kurik \\
3 & Kaca (Parambasis sp.) & - & Merauke dan Muting \\
4 & Kakap batu (Datnicides & 850 & Muting \\
5 & microlepis) & 520 & Merauke dan Muting \\
6 & Rainbow (Melanoteania sp.) & - & Merauke dan Muting \\
7 & Udang hias & 900 & \\
8 & Sembilang (Taudonus sp.) & t.a & Merauke, Muting, Okaba, dan Kurik \\
9 & Sumpit (Toxotes sp.) & t.a & Merauke, Muting, Okaba, dan Kurik \\
10 & Katip (Morgumda sp.) & t.a & Merauke, Muting, Okaba, dan Kurik \\
11 & Iriatherina (Iriatherina werneri) & t.a & Merauke dan Muting \\
\hline
\end{tabular}

Sumber: Dinas Perikanan dan Kelautan Kabupaten Merauke (2005a); Dinas Perikanan dan Kelautan Kabupaten Merauke (2005b)

Beberapa ikan yang terdapat di Sungai Maro dapat dikembangkan sebagai ikan konsumsi (Gambar 2) yang bernilai ekonomi tinggi seperti ikan kakap rawa, sembilan, mata bulan, bulanak, kakap kembang, lobster, gastor, tulang, tiga duri, betok, serta udang putih. Ikan yang berpotensi sebagai ikan konsumsi pada umumnya mempunyai ukuran besar, misal kakap rawa berukuran panjang total $89 \mathrm{~cm}$ yang menurut wawancara dengan nelayan setempat merupakan ukuran sedang sehingga kemungkinan dapat mencapai ukuran yang lebih besar. Produksi ikan di perairan umum Kabupaten Marauke disajikan pada Tabel 2. 


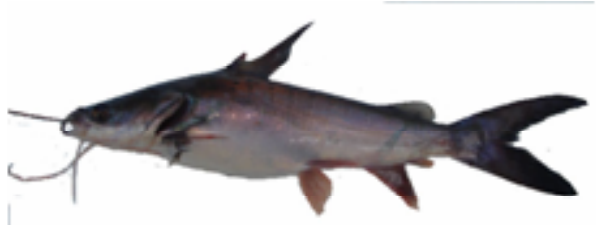

Tiga duri atau herkules (Arius latirostris)

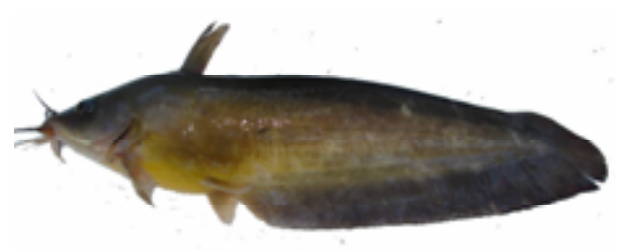

Sembilan (Taudonus sp.)

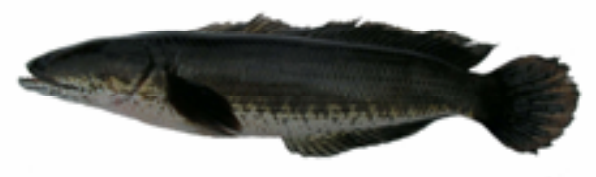

Gastor (Channa sp.)

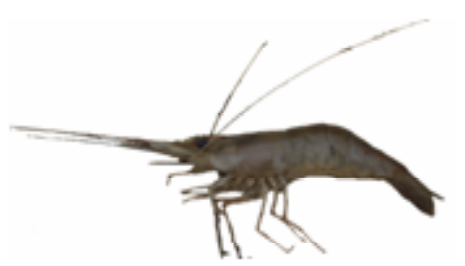

Udang putih (Macrobrachium

sp.)

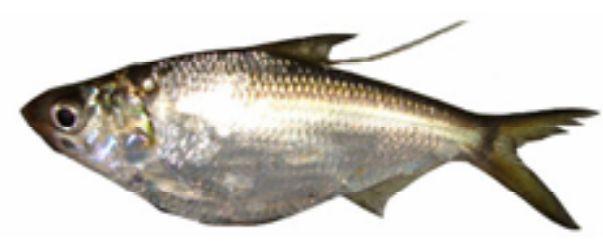

Tulang (Megalops cyprinoides)

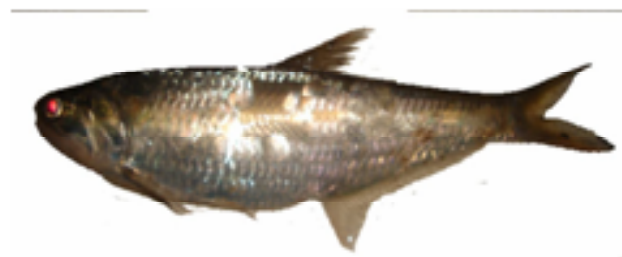

Mata bulan (Thryssa scratchieyl)

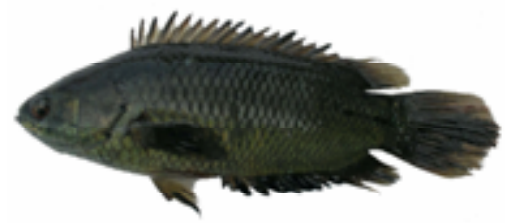

Betok (Anabas sp.)

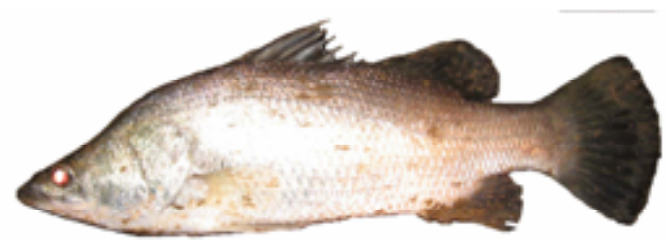

Kakap rawa (Lates calcarifer)

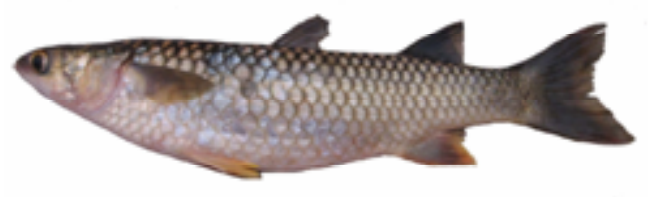

Bulanak (Valamugilsp.)

Gambar 2. Beberapa jenis ikan yang berpotensi sebagai ikan konsumsi. 
Tabel2. Produksi ikan perairan umum Kabupaten Merauke dalam kg, tahun 2004

\begin{tabular}{ccccccccc}
\hline No. & Distrik & $\begin{array}{c}\text { Betok/ } \\
\text { Betik }\end{array}$ & Mujair & Lele & $\begin{array}{c}\text { Gabus/ } \\
\text { Gastor }\end{array}$ & $\begin{array}{c}\text { Udang } \\
\text { galah }\end{array}$ & $\begin{array}{c}\text { Kakap } \\
\text { rawa }\end{array}$ & Jumlah \\
\hline 1 & Merauke & 22.838 & 33.987 & 81.932 & 703.350 & 935 & 26.250 & 869.292 \\
2 & Semangga & 21.500 & 36.000 & 20.150 & 38.000 & 345 & 3.800 & 119.795 \\
3 & Tanah Miring & 4.500 & 12.500 & 13.025 & 11.500 & 1.095 & 2.200 & 44.820 \\
4 & Kurik & 3.500 & 23.682 & 20.150 & 114.963 & 1.800 & 18.750 & 182.845 \\
5 & Jagebob & 35.894 & 19.868 & 28.170 & 24.604 & 860 & 5.187 & 114.583 \\
6 & Okaba & 25.300 & 11.800 & 17.250 & 38.500 & 950 & 16.219 & 110.019 \\
7 & Sota & 11.856 & 8.892 & 14.820 & 17.784 & & 5.928 & 59.280 \\
8 & Elikobel & 13.460 & 3.673 & 1.745 & 3.632 & 972 & 8.733 & 32.215 \\
9 & Ulilin & 15.255 & 1.093 & 1.896 & 1.304 & 866 & 15.938 & 36.352 \\
10 & Muting & 17.947 & 3.122 & 1.880 & 3.259 & 735 & 10.086 & 37.029 \\
11 & Kimaam & 7.178 & & 260 & 365 & 355 & 267.263 & 275.421 \\
\hline & Jumlah & $\mathbf{1 7 9 . 2 2 8}$ & $\mathbf{1 5 4 . 6 1 7}$ & $\mathbf{2 0 1 . 2 7 8}$ & $\mathbf{9 5 7 . 2 6 1}$ & $\mathbf{8 . 9 1 3}$ & $\mathbf{3 8 0 . 3 5 4}$ & $\mathbf{1 . 8 8 1 . 6 5}$ \\
\hline
\end{tabular}

Sumber: Dinas Perikanan dan Kelautan Kabupaten Merauke (2005b)

Ikan hasil tangkapan di Sungai Maro pada bulan Nopember 2006 dengan menggunakan gill net percobaan ukuran mata jaring 2 dan 2,5 inci berdasarkan pada jumlah individu didominasi oleh ikan tulang $(51,52 \%)$ dan ikan duri $(25 \%)$ sedangkan berdasarkan pada bobot total per individu didominasi

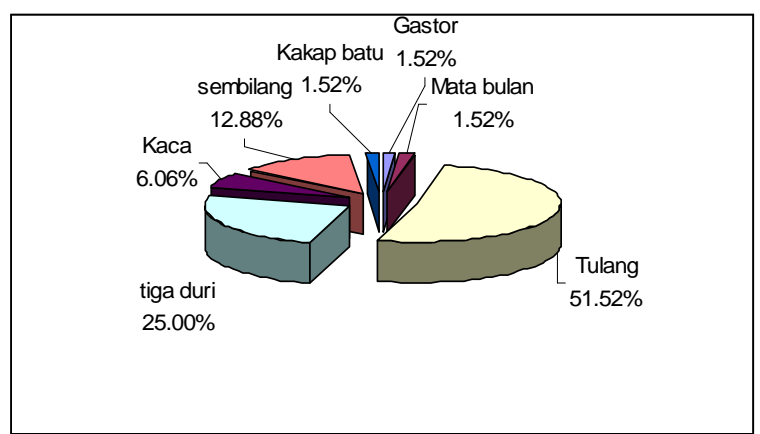

Gambar 3. Komposisi hasil tangkapan berdasarkan pada jumlah individu. oleh ikan tulang $(59,84 \%)$ dan sembilan $(14,91 \%)$ (Gambar 3 dan 4).

Komposisi hasil tangkapan berdasarkan pada jumlah individu menggunakan jala lempar dengan ukuran mata jaring 0,5 inci didominasi oleh udang putih $(72,22 \%)$ seperti disajikan pada gambar 5 .

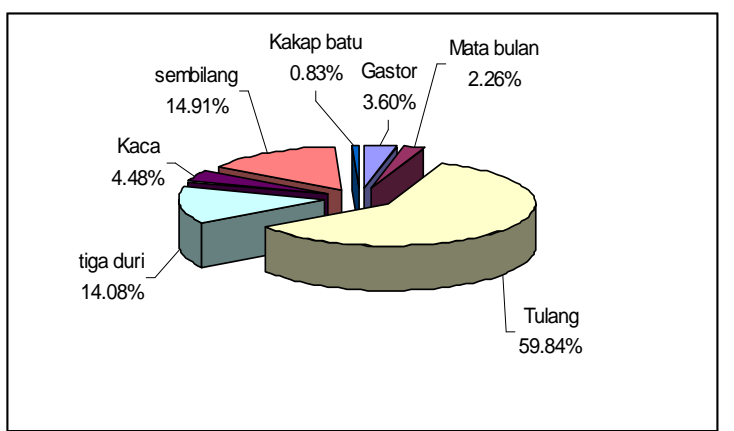

Gambar 4. Komposisi hasil tangkapan berdasarkan pada bobot total.

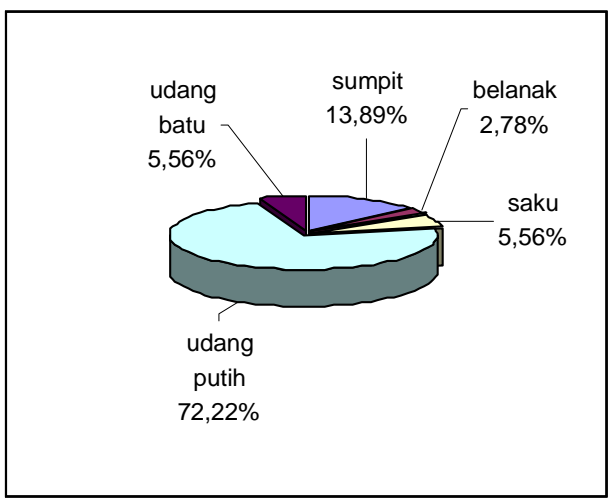

Gambar 5. Komposisi hasil tangkapan berdasarkan pada jumlah individu menggunakan jala lempar dengan ukuran mata jaring 0,5 inci. 


\section{UPAYA PELESTARIAN SUMBER DAYA IKAN}

Menurut Undang-Undang No.5 tahun 1990, sumber daya alam hayati adalah unsur-unsur hayati di alam yang terdiri atas sumber daya alam nabati (tumbuhan) dan sumber daya alam hewani (satwa) yang bersama dengan unsur non hayati di sekitar secara keseluruhan membentuk ekosistem. Sungai Maro mempunyai kekayaan plasma nutfah ikan asli Papua. Sungai ini juga merupakan salah satu sumber penghidupan masyarakat setempat yang berprofesi sebagai nelayan. Ikan-ikan yang terdapat di sungai ini berpotensi untuk dikembangkan sebagai ikan konsumsi karena memiliki ukuran yang besar serta daging yang tebal. Oleh karena itu, potensi dan pemanfaatan perlu dikelola dengan sebaik-baik agar potensi sumber daya plasma nutfah perikanan tidak punah, salah satu cara adalah dengan melakukan konservasi habitat. Habitat yang sesuai akan mendukung organisme air hidup dan berkembang secara alami.

Konservasi dapat diartikan sebagai usaha pengelolaan yang dilakukan oleh manusia dalam memanfaatkan biosfir sehingga dapat menghasilkan keuntungan sebesar-besar secara berkelanjutan untuk generasi sekarang serta tetap memelihara potensi untuk memenuhi kebutuhan generasi yang akan datang. Konservasi sumber daya alam hayati adalah pengelolaan sumber daya alam hayati yang pemanfaatan dilakukan secara bijaksana untuk menjamin kesinambungan persediaan dengan tetap memelihara dan meningkatkan kualitas keanekaragaman dan nilai. Konservasi mencakup berbagai aspek positif yaitu perlindungan, pemeliharaan, pemanfaatan secara berkelanjutan, dan pelestarian. Konservasi bertujuan menurut strategi konservasi sedunia ada 3 yaitu:

a. Memelihara proses ekologi yang esensial dan sistem pendukung kehidupan.

b. Mempertahankan keanekaragaman genetis.

c. Menjamin pemanfaatan jenis (spesies) dan ekosistem secara berkelanjutan.

Dari uraian di atas, tidak ada larangan bagi manusia dalam memanfaatkan varietas, jenis, dan ekosistem yang ada di sekitar (Kehati, 2000). Pengertian konservasi sumber daya alam hayati dan ekosistem mengandung 3 aspek yaitu:

a. Perlindungan sistem penyangga kehidupan.

b. Pengawetan dan pemeliharaan jenis tumbuhan dan satwa serta ekosistem.

c. Pemamfaatan secara lestari sumber daya alam hayati dan ekosistem (Undang-Undang No.5 tahun 1990 pasal 5).
Berdasarkan pada uraian di atas, maka perlu diperhatikan pemanfaatan yang berwawasan lingkungan dalam memanfaatkan sumber daya alam ikan (Hardjasoemantri, 2000). Hal yang perlu diperhatikan adalah cara penangkapan yang harus ramah lingkungan. Cara penangkapan yang tidak ramah lingkungan seperti penggunaan racun atau bom ikan selain akan merusak ekosistem juga akan membunuh benih ikan. Selain itu, kuantitas atau jumlah, waktu, dan daerah tangkapan. Jumlah ikan yang ditangkap harus mempertimbangkan prinsip kelestarian lingkungan yaitu maksimum suistanable yield. Penangkapan juga harus memperhatikan waktu dan tempat, dilarang menangkap ikan pada saat ikan akan memijah dan di tempat yang merupakan habitat ikan tersebut untuk memijah, jadi harus mempertimbangkan ada suaka perikanan (reservat).

Untuk menjaga kelestarian populasi ikan arwana Irian telah ditetapkan Peraturan Menteri Kehutanan No.P.12/Menhut-II/2005 tentang perubahan keputusan Menteri Kehutanan No.2091/Kpts-II/2001 tentang penetapan ikan arwana irian (Scleropages jardinii) sebagai satwa buru. Penangkapan ikan ini berlangsung selama 60 hari pada bulan November, Desember, Januari, dan Pebruari. Berdasarkan pada Peraturan Menteri tersebut, cara penangkapan ikan tidak menggunakan racun, tidak membunuh induk untuk mengambil anak atau cara lain yang tidak sesuai dengan prinsip konservasi.

\section{KESIMPULAN}

Jenis-jenis ikan yang merupakan kekayaan plasma nutfah di Sungai Maro dapat dibagi menjadi 2 kategori yaitu ikan hias antara lain arwana Irian (Sclerophages jardinit), sumpit (Toxotes sp.), kurikil (Datnioides sp.), udang batu cherax (Cherax albertisı), kakap kembang (Golssamia apton), kaca (Parambassis sp.), tung (Apogon sp.), saku (Strongylura kreffti), dan ikan konsumsi antara lain tiga duri atau herkules (Arius latirostris), tulang (Megalops sp.), sembilan (Taudonus sp.), mata bulan (Thryssa scratchleyi), gastor (Channa sp.), betok (Anabas sp.), udang putih (Macrobrachium sp.), kakap rawa (Lates calcarifer), dan bulanak (Valamugil $\mathrm{sp})$.

\section{PERSANTUNAN}

Hasil dari kegiatan riset pemacuan stok dan konservasi sumber daya perikanan di Danau Sentani dan Sungai Maro T.A. 2006 di Loka Riset Pemacuan Stok Ikan 


\section{DAFTAR PUSTAKA}

Allen, G. R. 1991. Field guide to the freshwater fishes of New Guinea. Cristensen Research institute. PNG.

Allen, G. R., Kent G., Hortle, \& Samuel J. R. 2000. Freshwater fishes of the Timika Region New Guinea. P. T. Freeport Indonesia. Timika.

Anonim (Kehati). 2000. Ekosistem air tawar dan keanekaragaman hayati. Warta Kehati Edisi Maret-April. 3-5.

Dinas Perikanan dan Kelautan Kabupaten Merauke. 2005a. Laporan tahunan 2004.

Dinas Perikanan dan Kelautan Kabupaten Merauke. 2005b. Database perikanan Kabupaten Merauke tahun 2004.

Hardjasumantri, K. 2000. Hukum tata lingkungan. Universitas Gadjah Mada. Press. Yogyakarta.
Kehati. 2000. Ekosistem air tawar dan keanekaragaman hayati. Warta Kehati. Edisi Maret-April. 3-5.

Pusat Riset Perikanan Tangkap. 2005. Dukungan riset untuk pemanfaatan, pengelolaan, dan pelestarian keanekaragaman hayati ikan di perairan pedalaman wilayah wallacea. Diakses dari www.unhasalumninet.com/makalah/Makalah biodiversity wallacea.doc tanggal 16 Agustus 2005.

Tjakrawidjaja A. H. \& Haryono. 2003. Studi populasi ikan kaloso (Scleropages jardinii) di Rawa Pomo Kecamatan Citak Mitak Kabupaten Merauke, Papua. Berita Biologi. Vol.5 (4): 357-364.

Undang-Undang No. 5 tahun 1990 tentang konservasi sumber daya alam hayati dan ekosistemnya.

Undang-Undang No.31 tahun 2004 tentang perikanan diakses dari www.dkp.go.id

Undang-Undang No.7 tahun 2004 tentang sumber daya air. Fokus Media. Bandung. 